\title{
The Unsaponifiable Fraction of Certain Oils.
}

IN attempting to concentrate the fat-soluble vitamins, investigators submitted the fats or oils containing them to saponification, and found that they passed unchanged into the unsaponifiable fraction. Subsequent work, especially in connexion with vitamin $A$, has led to increased knowledge of the constituents of this fraction of a number of natural oils and fats, although the identification of the vitamin itself has not been successful. At the same time a certain amount of attention has been directed to the physiological functions of some of these constituents. It may be of interest to review briefly some of the more recent work on this subject.

\section{Fish Oils : Chemrstry.}

It is only natural that the unsaponifiable matter of cod-liver oil should have been thoroughly investigated, considering its importance as a source of supply of vitamins $A$ and $D$; much attention has been devoted to it, especially in Great Britain and Japan. Its content of unsaponifiable matter is, however, only small, about 0.7 per cent of the oil ; and half of this consists of cholesterol. In the other portion, Drummond and his colleagues have identified small amounts of squalene $\mathrm{C}_{30} \mathrm{H}_{50}$, and batyl alcohol $\mathrm{C}_{21} \mathrm{H}_{44} \mathrm{O}_{3}$ : they also found a small quantity of a hydrocarbon (unidentified), but considered that the main constituents are one or more unsaturated alcohols, possibly oleyl or selachyl alcohols (J. C. Drummond, H. J. Channon, and K. H. Coward, Biochem. J., vol. 19, p. 1047; 1925 ; J. C. Drummond and L. C. Baker, ibid., vol. 23, p. 274 ; 1929). Nakamiya and Kawakami (Scient. Papers, Inst. Chem. Phys. Res., vol. 7, p. 121 ; 1927) claim to have isolated, amongst other products after the hydrogenation of the cod-liver oil concentrate, nonacosane $\mathrm{C}_{29} \mathrm{H}_{60}$ and batyl alcohol, but the identified compounds constitute only a small portion of the whole. They were, however, unable to detect squalene in their samples of cod-liver oil. Weidemann considers that the alcohols present are more unsaturated than selachyl alcohol (Biochem. J., vol. 20, p. 685 ; 1926).

Certain other fish liver oils contain larger amounts of unsaponifiable matter, which is more easily fractionated than that obtained from cod-liver oil. That from the Greenland shark has been investigated by, amongst others, Drummond and Baker (loc. cit.) and Weidemann (loc. cit.). It contains about 15 per cent, of which cholesterol constitutes only about 14 per cent. Squalene is present in minute amounts $(0.5$ per cent of the unsaponifiable matter) ; the rest of this fraction consists chiefly of batyl (about 20 per cent), selachyl $\left(\mathrm{C}_{21} \mathrm{H}_{42} \mathrm{O}_{3}\right)$ and oleyl $\left(\mathrm{C}_{18} \mathrm{H}_{35} \mathrm{OH}\right)$ alcohols. The presence of the last two was indicated by the detection of batyl, and probably octadecyl, alcohols after hydrogenation.

The liver oil of the Japanese shark contains about 5 per cent unsaponifiable matter. Small amounts of cholesterol and possibly squalene were detected; chimyl alcohol $\left(\mathrm{C}_{19} \mathrm{H}_{40} \mathrm{O}_{3}\right)$ is present to the extent of about 20 per cent, whilst the rest of the fraction is composed chiefly of selachyl alcohol.

Drummond and Baker reduced chimyl alcohol with hydriodic acid and obtained cetyl iodide and isopropyl iodide: their results indicated that the alcohol is a monoglyceryl ether of cetyl alcohol. Heilbron and Owen have shown that batyl alcohol is an ether of octadecyl alcohol and glycerol; it probably has the formula $\mathrm{CH}_{3} \cdot\left(\mathrm{CH}_{2}\right)_{17} \cdot \mathrm{O} \cdot \mathrm{CH} \cdot\left(\mathrm{CH}_{2} \mathrm{OH}\right)_{2}$, since it is optically inactive (Drummond, Chem. and Ind., vol. 49 , p. $1, T ; 1930$ ).

The hydrocarbon squalene contains six double bonds; it forms a characteristic hexahydrochloride by which it can be easily identified. Channon has investigated its distribution in certain fish, and found it to be present in the liver oils of only three members of the Squalidæ family: it has, however, also been found in the livers of certain Japanese elasmobranchs (Biochem. $J$., vol. 22 , p. 51 ; 1928). It seems unlikely that it can be derived from the food; in any case it was not found in the samples of plankton examined. The unsaponifiable matter of the liver oils of these fish formed a very high proportion of the oil, 67-73 per cent; other fish contained up to 33 per cent. In general the unsaponifiable fraction was considerably greater than in mammalian livers. It was noticed that in the Selachii there was an inverse relationship between the amount of unsaponifiable matter present and its sterol content, independent of whether squalene was present or not. There appears to be no relationship between the sterol and squalene.

\section{Fish Orls : Physiology.}

Channon has investigated the results of administering certain of these higher alcohols and squalene to mammals. He found that rats absorbed a certain amount of the latter when fed in daily doses not exceeding 0.075 c.c. a day or mixed to the extent of 1 per cent in the diet. In some of the experiments the fæces were collected during their course and worked up at the end with the livers and bodies of the animals; in others, only the livers were examined for the presence of squalene (Biochem. J., vol. 20, p. 400 ; 1926). The fæces were extracted with alcohol and ether, and the extract then treated as the other material. Saponification was followed by ether extraction of the unsaponifiable matter, which was again saponified and the solution extracted with ether. Cholesterol was removed with digitonin and the mother liquors extracted with ether. The residue, after removal of the solvent, was again dissolved in ether, and dry hydrochloric acid gas passed through the solution. The squalene hexahydrochloride so obtained was recrystallised from acetone. In one experiment, $2.77 \mathrm{gm}$. squalene were given to each rat over a period of 6 weeks; $1.7 \mathrm{gm}$. was excreted. The unsaponifiable matter in the liver was increased up to $2 \frac{1}{2}$ times that in the controls on the same diet and was half as much again in the carcass (without liver). The cholesterol content in the liver was doubled. The squalene actually recovered from the liver, however, only accounted for about half of the unsaponifi. able matter left after removal of the cholesterol. The increase in the cholesterol with increase in the total unsaponifiable matter is the reverse of the relationship found in the fish oils mentioned above.

In further experiments with Collinson (Biochem. J., vol. 22, p. $391 ; 1928$ ) it was found that rats absorbed about $0.045 \mathrm{gm}$. daily of oleyl alcohol and phytol, $0.03 \mathrm{gm}$. up to $0.09 \mathrm{gm}$. of cetyl alcohol, and $0.017 \mathrm{gm}$. of cholesterol : the two latter were given in dispersion in olive oil. Phytol appeared to be more readily absorbed than oleyl alcohol. These two increased the amount of unsaponifiable matter in the liver, and at the same time the cholesterol content was raised. Cetyl alcohol had no influence upon this fraction of the liver fat. The administration of cholesterol increased it four times, and the whole of this increase was accounted for by the deposition in the organ of cholesterol itself. It was also observed that the solubilities of these alcohols in bile follow the same order as the degrees to which they are absorbed. From some experiments of Mellanby with emulsified fat and squalene, it appears that particulate absorp-

No. 3157, VoL. 125] 
tion of fatty substances may occur in the intestine, but only in the presence of bile.

These results led to a re-examination of the question as to whether liquid paraffin can be absorbed from the gut ; rats and a pig were used (Channon and Collinson, ibid., vol. 23, p. $676 ; 1929$ ). Reliance was placed on the iodine value of the unsaponifiable fraction of the liver, together with an estimation of its cholesterol content to determine the presence of paraffin in this organ. The rats were given 5 per cent paraffin in the diet for five weeks, the pig 100 c.c. daily, mixed with gum acacia mucilage and a little food, for about eight weeks. The unsaponifiable matter in the livers of the paraffin-fed rats was increased 40 per cent; the cholesterol percentage was reduced, but the absolute amount was unchanged as compared with the controls; the iodine value of the non-sterol fraction was 31 instead of 119. Similar results were obtained in the case of the pig ; in addition, a saturated hydrocarbon was actually isolated. The non-sterol fraction (expressed as a percentage of the liver weight) was increased $3 \frac{1}{2}$ times in the rats and $2 \frac{1}{2}$ times in the pig ; but its iodine value in the latter was decreased to a third of that of the control.

\section{Mammanian OILS aNd FATS.}

Channon and Marrian have found an unsaturated hydrocarbon in mammalian liver, which is probably not squalene, although closely allied to it (Biochem. $J$., vol. 20 , p. 409 ; 1926). The unsaponifiable material was prepared from the livers of the pig, sheep, ox, horse, and man; the yields were $0 \cdot 3-0 \cdot 4$ per cent. More than half of the material consisted of cholesterol, and pigments were also present. The hydrocarbon was obtained as a crystalline hydrochloride or an amorphous bromide, both of which are insoluble in ether, whereas the cholesterol compounds are soluble; by use of either method the hydrocarbon can be separated from the latter. Considerable purification was effected by making use of the fact that the hydrocarbon is insoluble in methyl alcohol, but it was not obtained in the pure state. It could not be distilled at $2 \mathrm{~mm}$. Hg. pressure, decomposition occurring. The hydrochloride and bromide were analysed, but molecular weight determinations could not be carried out, since the hydrocarbon was not prepared in the pure state, and the salts are very insoluble and decompose at high temperatures. No squalene was found in these livers. The same hydrocarbon has also been detected by Drummond and Baker (loc. cit.) in sheep-liver fat.

Certain members of the petrel family store in their stomachs an oil, to which attention has been directed from the fact that it contains vitamins $A$ and $D$. Rosenheim and Webster have examined the stomach oil of the fulmar petrel, which breeds on St. Kilda (Biochem. $J$., vol. 21, p. 111 ; 1927). It was found that the oil is a liquid wax containing nearly 40 per cent of unsaponifiable matter; unsaturated higher alcohols and clupanodonic acid were found to be present, but there was only a small amount of glycerol ; cetyl alcohol was not detected. In many respects the oil resembles sperm oil. The authors suggest that the bird uses the oil as a preening material. Both vitamins $\mathrm{A}$ and $\mathrm{D}$ were present.

Leigh-Clare has also found vitamin $\mathbf{D}$ in the stomach oil of the Australian petrel or 'mutton-bird' (ibid., vol. 21, p. $725 ; 1927)$. Carter and Malcolm have also carried out investigations on mutton-bird oil (ibid., vol. 21, p. 484; 1927). They consider that it consists largely of cetyl oleate together with esters of related alcohols and acids; it contains only traces of glycerol and little cholesterol. The origin of the oil is obscure. Experiments indicated that it could be digested in vitro by pig's pancreatic lipase, and that small amounts could be absorbed by the cat or the rat; cetyl alcohol in olive oil was also absorbed by the latter animal, a result which was confirmed later by Channon and Collinson, as mentioned above. Carter and Malcolm suggest that the presence of the oil in the stomach may be accidental, and that it is the tail gland secretion which has been swallowed.

Ether-soluble Substances in Plants.

Channon and Chibnall have investgated the ethersoluble substances of cabbage leaf cytoplasm (Biochem. $J$., vol. 21 , pp. $225,233,479,1112$; 1927 : vol. 23 , pp. 168 and $176 ; 1929$ ). The material was prepared by mincing the leaves with water and squeezing through silk; the filtrate was then heated to $70^{\circ}$, when the cytoplasm was coagulated, and could be collected and pressed to free from excess water. The dried material was powdered and extracted with ether. From a third to a half of the total cytoplasm was extracted from the leaf; the ratio of the protein to the ether-soluble substances present is 3 to 1 . The total amount of the latter in the leaf cytoplasm is about 3.5 per cent of the total leaf solids. Further fractionation was obtained by the use of solvents; soluble in acetone ether but insoluble in light petroleum are the pigments, chlorophyll 9.3 per cent, carotin 0.5 per cent, and xanthophyll 0.8 per cent of the total ether-soluble material ; soluble in ether acetone and light petroleum, the glycerides and waxes-the fatty acids accounting for $\mathbf{1 7 . 5}$ per cent and glycerol for 1.3 per cent, and unsaturated unsaponifiable matter consisting of stèrols 4.5 per cent, and unidentified compounds, probably alcohols and hydrocarbons, 13.3 per cent. The fraction insoluble in ether acetone could be subdivided into a fraction insoluble in hot acetone - calcium phosphatidate 18.4 per cent, unidentified calcium salts, possibly of fatty acids and phosphoric acid 5.0 per cent, and an unidentified iron compound 3.0 per cent, and a fraction soluble in hot acetone, the saturated unsaponifiable matter consisting chiefly of nonacosane and di-n-tetradecyl ketone, 12.3 per cent. There is an apparent loss of 14 per cent during the fractionations, the greater part of which is due to mechanical working losses, but it is possible that 5 per cent represents some other compounds, possibly hydroxyacids.

In the glyceride fraction, the results obtained suggested that palmitic, stearic, linolenic, and linolic acids were present, and possibly oleic acid also; palmitic accounted for two-thirds of the saturated acids and stearic for the remainder. The yield of fatty acids was higher in winter cabbage, that of the saturated unsaponifiable matter lower in winter than in summer.

Considerable attention was directed to the phosphatides; little if any phospholipin was detected, the major part of the ether-soluble phosphorus being present in the form of the calcium salt of a diglyceride phosphoric acid. The free acid and its lead salt were prepared, and barium glycerophosphate was also made from the former. The fatty acids present in the molecule appear to be stearic, palmitic, linolenic, linolic, or possibly oleic. The greater part of the acids in the molecule is unsaturated, whereas in lecithin and kephalin saturated and unsaturated acids are present in equimolecular proportions. The authors consider that phosphatidic acid may be a precursor of the lecithin and kephalin found in animal tissues rather than an in vitro decomposition product. There is already evidence in existence that calcium can be extracted from tissues with the kephalin fraction. The acid is a brownish oil, soluble in organic solvents, slightly soluble in water; the sodium salt is soluble in water, slightly soluble in cold alcohol, and insoluble

No. 3157, VoL. 125] 
in ether; the barium, calcium, and lead salts are insoluble in water, acetone, and alcohol, but soluble in ether.

Nearly one-haif of the phosphatide fraction is soluble in hot acetone. After purification by saponification, recrystallisation, and distillation, a material resembling paraffin wax was obtained, but the melting-point was indefinite, indicating that it was a mixture. By fractional distillation at $0 \cdot 1 \mathrm{~mm}$. pressure and crystallisation from benzene-alcohol, the hydrocarbon $\mathrm{C}_{29} \mathrm{H}_{60}$ was obtained in the pure state. The formula was confirmed by $\mathrm{X}$-ray analysis. The higher boiling fractions from the distillation were treated with hydroxylamine; the ketoxime was separated from the hydrocarbon by means of its greater solubility in light petroleum and acetone, and the ketone finally regenerated by boiling in hydrochloric acid alcohol. X-ray analysis indicated that it was either $\mathrm{CH}_{3} \cdot\left(\mathrm{CH}_{2}\right)_{13} \mathrm{CO} .\left(\mathrm{CH}_{2}\right)_{13} \mathrm{CH}_{3}$ or $\mathrm{CH}_{3} \cdot\left(\mathrm{CH}_{2}\right)_{14} \cdot \mathrm{CO} .\left(\mathrm{CH}_{2}\right)_{12} \cdot \mathrm{CH}_{3}$; both were accordingly synthesised, when it was found that the substance was di- $n$-tetradecyl-ketone. Nonocosane and the ketone occur in the ratio of 3 to 1 . Small quantities of other unidentified substances are also present in this fraction of the cytoplasm.

Maclean and her co-workers (Biochem. J., vol. 23, pp. 107 and 634 ; 1929) have also isolated from cabbage leaves nonacosane and di-n-tetradecyl-ketone; from spinach leaves, however, the hydrocarbon hentriacontane, $\mathrm{C}_{31} \mathrm{H}_{64}$, was obtained.

In conclusion, it may be mentioned that Maclean has isolated from yeast fat a second sterol which she has named 'zymosterol'. 'The crude sterol was separated, by recrystallisation from alcohol, ether, and acetone, into the less soluble ergosterol, m.p. $158 \cdot 5^{\circ}$, and a sterol, m.p. $108^{\circ}-109^{\circ}$ (zymosterol) (ibid., vol. 22 , p. $22 ; 1928$ ). The latter is dextrorotatory (in ethereal solution), the former lavorotatory (in chloroform). It probably has the same number of ethenoid linkages as ergosterol and a very similar structure; it is precipitated by digitonin, but shows no selective absorption in the ultra-violet. It cannot be converted into vitamin $D$ by irradiation (ibid., p. 980$)$.

\section{International Congress of Archæology and Anthropology, Portugal, I930.}

$\mathrm{R}$

ADERS of NATURE will have in mind the recent criticisms of the international standing of the congresses in archæology and anthropology which have been held since the War under the auspices of the Institut International d'Anthropologie of Paris. These were summarised in the leading article in our issue of Mar. 1. In the recently issued announcement of the Congress to be held in Portugal on Sept. 21-30 next, it would now appear that the promoters hope to meet objections which have been raised on the ground that the Congress is not truly international in character by indicating that this congress will be a continuation of the older series of the International Congresses in Anthropology and Prehistoric Archæology, of which the last was held at Geneva in 1912. The invitation is issued jointly by the Conseil permanent du Congrès International d'Anthropologie et d'Archéologie Préhistorique and the Institut International d'Anthropologie. It is announced as the " $\mathrm{xv}^{\mathrm{e}}$ Congrès International d'Anthropologie et d'Archéologie Préhistorique" and the "ive Session de l'Institut International d'Anthropologie " ; finally, it is pointed out that the meeting coincides with the fiftieth anniversary of the Congress held in Lisbon in 1880 .

While welcoming with all good will this expression of the desire of the members of the Institut that the congress should be regarded as truly international, it must be pointed out that it is not sufficient to call it so, or even to announce that it is a continuation of a former congress which has not met for eighteen years. The only international element in the organisation is the committee in charge of the preparation of the scientific proceedings, which, it is understood, has no executive power and on which Great Britain is not represented. The committees responsible for local arrangements at Coimbra and Oporto naturally are entirely local, but the publications committee is French with two exceptions. The real executive of the Congress, we presume, is constituted as before. The invitation is issued from the Siège Social of the Institut, namely, the Écoled'Anthropologie, and notfromLisbon.

Of the "Conseil permanent " of the older Congress, M. Marcellin Boule is a member of the Comite d'Honneur, and M. Pittard represents Switzerland on the committee in charge of the preparation of the scientific proceedings.

The Congress will be divided into sections, of which the first will deal with questions of morphological anthropology and functional ethnology, among the points specifically mentioned in this division being the methods of anthropology and especially the interpretation of statistics, the human brain from the racial point of view, endocrinology and human morphology, and the relation between the yellow races of Africa (Bushman) and the yellow races of Asia.

The second section will deal with human palæontology and prehistoric archæology, in which the question of the Kitchen midden people of Portugal, Armorica, and Denmark will be discussed. Another subject will be the distribution of cereals in neolithic times as well as the origin of domestic animals, particularly the dog.

The third section will deal with heredity, eugenics and cognate subjects, including criminology and psycho-sociology.

The fourth section is of a comprehensive character, covering ethnography, folklore, linguistics, religions, and human geography. One topic of discussion specifically mentioned is the geographical and ethnic origin of the Aurignacians. Primitive survivals among civilised peoples should give rise to lively discussion.

The session will be formally declared open by His Excellency the Minister of Public Instruction, Prof. Gustavo C. Ramos, on Sept. 21, at Coimbra, and a dinner will be given by the Rector of the University on the same day. On the following days, after the work of the sections has closed, conversaziones or illustrated lectures will be given in the evening. On Sept. 26 an archæological excursion will be made to Figueira da Foz on the way to Oporto. On Sept. 26 the Congress reopens at Oporto, on the evening of which day there will be a folk-lore fête at the Palais du Cristal, and on Sept. 27 the Congress will be formally declared closed, a banquet being held after. wards. On Sunday a motor expedition of archæological interest will be made to Guimaraes and Citania de Briteiros. The Congress will arrive at Lisbon on Monday, Sept. 29, at midday. A formal reception will be held by His Excellency General Carmona, President of the Portuguese Republic, and the following and final day will be spent in visits to museums and other places of interest.

Intimation of intention of attending the Congress and subscriptions should be addressed to le Trésorier de l'Institut International, 15 rue de l'École de Médecine, Paris $\left(6^{\mathrm{e}}\right)$.

No. 3157, Vot. 125] 